\title{
Clinical Applications of Natriuretic Peptides in Heart Failure and Atrial Fibrillation
}

\author{
Masako Baba ${ }^{1,2}$, Kentaro Yoshida ${ }^{1,2, *}$ and Masaki Ieda ${ }^{1}$ (D) \\ 1 Department of Cardiology, Faculty of Medicine, University of Tsukuba, Tsukuba 305-8575, Japan; \\ babamasako1010@yahoo.co.jp (M.B.); mieda@md.tsukuba.ac.jp (M.I.) \\ 2 Department of Cardiology, Ibaraki Prefectural Central Hospital, Kasama 309-1793, Japan \\ * Correspondence: kentaroyo@nifty.com; Tel.: +81-29-853-3142
}

Received: 12 April 2019; Accepted: 7 June 2019; Published: 10 June 2019

\begin{abstract}
Natriuretic peptides (NPs) have become important diagnostic and prognostic biomarkers in cardiovascular diseases, particularly in heart failure (HF). Diagnosis and management of coronary artery disease and atrial fibrillation (AF) can also be guided by NP levels. When interpreting NP levels, however, the caveat is that age, sex, body mass index, renal dysfunction, and race affect the clearance of NPs, resulting in different cut-off values in clinical practice. In AF, NP levels have been associated with incident AF in the general population, recurrences after catheter ablation, prediction of clinical prognosis, and the risk of stroke. In this article, we first review and summarize the current evidence and the roles of B-type NP and atrial NP in HF and coronary artery disease and then focus on the increasing utility of NPs in the diagnosis and management of and the research into AF.
\end{abstract}

Keywords: natriuretic peptides; heart failure; atrial fibrillation; remodeling

\section{Introduction}

Natriuretic peptide (NP) levels are now widely measured in clinical practice and have been extensively assessed in cardiovascular research throughout the world. B-type natriuretic peptide (BNP) and N-terminal proBNP (NT-proBNP) are the most commonly used to diagnose heart failure (HF) [1-3]. In addition, diagnosis and management of acute coronary syndrome (ACS) $[4,5]$ and atrial fibrillation (AF) [6] can be guided by NP levels. Although the use of NP has been slow to permeate AF care compared with that for HF and ACS, several studies reported the utility of NPs for the diagnosis and treatment of AF over the last decade [7-9]. Recently, the 2016 European Society of Cardiology (ESC) guidelines on the management of AF recommended using NPs to further refine the risks of stroke and bleeding in AF patients as a class IIb recommendation with the level of evidence B [10]. In this article, we first review and summarize the current evidence and roles of BNP and atrial natriuretic peptide (ANP) in HF and ACS and then focus on the increasing utility of NPs in the diagnosis and management of and research into AF from the viewpoint of electrophysiologists routinely performing catheter ablation of AF.

\section{Roles of NP: BNP and ANP}

Both ANP and BNP are synthesized as pre-prohormones. ANP is primarily expressed and stored in the atrium. The primary stimulus for ANP release is atrial wall stretch resulting from increased intravascular volume [11]. ANP is translated into prepro-ANP that is cleaved into pro-ANP, which is stored in intracellular granules. The plasma level of ANP in healthy individuals is approximately $20 \mathrm{pg} / \mathrm{mL}$ and is evaluated to be 10-100-fold higher in patients with HF [12]. The half-life of ANP is approximately 2 min [13]. The clearance of ANP mainly occurs in the lung, liver, and kidney, with extraction ratios reported to be $24 \%, 30 \%$, and $35 \%$, respectively. In the kidney, a good correlation was 
shown between creatine clearance and ANP clearance $(r=0.58, p<0.05)$ [14]. BNP is minimally stored in granules in the ventricles and secreted directly in large bursts following stimulation [3,15]. The plasma level of BNP in healthy individuals is approximately $3.5 \mathrm{pg} / \mathrm{mL}$ and is evaluated to be 100 -fold higher in patients with HF [16]. The half-life of BNP is approximately $20 \mathrm{~min}$ [17]. Subsequently, the peptide is cleaved first into pro-BNP, then to biologically active BNP and the inactive NT-proBNP. BNP and NT-proBNP are secreted in equal concentrations, and the half-life of NT-proBNP is approximately $120 \mathrm{~min}$. BNP clearance is dependent on neutral endopeptidase, and NT-proBNP clearance is dependent on direct renal filtration [18]. In normal subjects, although the BNP concentration is much lower than the ANP concentration, the BNP concentration is markedly increased in patients with HF in proportion to its severity. Thus, the BNP concentration is increased to a much greater degree than is the ANP concentration [17] (Table 1).

Table 1. Summary of some clinically relevant physiologic characteristics of B-type natriuretic peptide (BNP), N-terminal proBNP (NT-proBNP), atrial natriuretic peptide (ANP), and mid-regional proANP (MR-proANP) [11-16].

\begin{tabular}{ccccc}
\hline Characteristic & BNP & NT-proBNP & ANP & MR-proANP \\
\hline $\begin{array}{c}\text { Localization within } \\
\text { heart }\end{array}$ & $\begin{array}{c}\text { Atrial and } \\
\text { ventricular }\end{array}$ & Same as BNP & Atrial & Same as ANP \\
\hline Storage & Minimal & Same as BNP & $\begin{array}{c}\text { In intracellular } \\
\text { granules }\end{array}$ & Same as ANP \\
\hline $\begin{array}{c}\text { Basal cardiac } \\
\text { secretion }\end{array}$ & $(+)$ & Same as BNP & ++ & Same as ANP \\
\hline $\begin{array}{c}\text { Gene transcription } \\
\text { response to stretch }\end{array}$ & Rapid & Same as BNP & Slow & Same as ANP \\
\hline Half-life (min) & 20 & $60-120$ & 2 & $60-120$ \\
\hline Biologically active & Yes & No & Yes & No \\
\hline Clinical range & $0-5000 \mathrm{pg} / \mathrm{mL}$ & $0-35,000 \mathrm{pg} / \mathrm{mL}$ & $0-2000 \mathrm{pg} / \mathrm{mL}$ & $0-1000$ pmol/L \\
\hline
\end{tabular}

BNP: B-type natriuretic peptide, NT-proBNP: N-terminal pro B-type natriuretic peptide, ANP: Atrial natriuretic peptide, MR-proANP: Mid-regional proANP.

Additionally, because ANP is labile and has a very short half-life, BNP is preferred for diagnostic and prognostic use in HF [19]. Tsutamoto et al. showed that in patients with chronic HF (left ventricular ejection fraction $[\mathrm{EF}]<45 \%)$, only the BNP level $(p<0.0001)$ was a significant independent predictor of mortality in patients with HF by Cox proportional hazard analysis, whereas the ANP level was not [20]. Some studies showed that in patients with HF, BNP is markedly increased in relation to HF severity and surpasses the levels of ANP [21,22]. Current guidelines have greatly affected the use of NP for the diagnosis and management of HF. The ESC guideline and the American Heart Association (ACCF/AHA) noted that measurements of BNP and NT-proBNP levels are useful (Class I) to support a clinical diagnosis of $\mathrm{HF}$ and to determine prognosis or disease severity in chronic HF and acutely decompensated HF [23,24].

\section{Screening for Asymptomatic Patients}

BNP and NT-proBNP can predict mortality and cardiovascular events in asymptomatic patients. McDonagh et al. studied a random sample of 1640 men and women aged 25-74 years and their four-year all-cause mortality rate. The median BNP in those who died was $16.9(8.8-27) \mathrm{pg} / \mathrm{mL}$ compared with $7.8(3.4-13) \mathrm{pg} / \mathrm{mL}$ in the survivors $(p<0.0001)$. One of the independent predictors of four-year all-cause mortality was BNP $>17.9 \mathrm{pg} / \mathrm{mL}(p=0.006)$ [25]. Similarly, in the large prospective study of the Framingham Offspring study, which included 3346 people without HF (mean follow-up of 5.2 years), those with a BNP above the 80 th percentile $(20.0 \mathrm{pg} / \mathrm{mL}$ for men and $23.3 \mathrm{pg} / \mathrm{mL}$ for women) 
were associated with multivariable-adjusted hazard ratios (HRs) of 1.62 for death, 1.76 for a first major cardiovascular event, 1.91 for AF, 1.99 for stroke or transient ischemic attack, and 3.07 for HF [26].

\section{Diagnosis of Acute HF}

Acute HF is often difficult to diagnose in the emergency department (ED). The symptoms are not specific and not sensitive. BNP and NT-proBNP are useful in establishing or excluding the diagnosis of acute HF. The large Breathing Not Properly Multinational Study, which first proved the efficacy of BNP, included 1586 patients with acute dyspnea in the ED. At a cut-off of $100 \mathrm{pg} / \mathrm{mL}$, the diagnostic accuracy of BNP was $83.4 \%$, whereas the negative predictive value of BNP at a cut-off of $<50 \mathrm{pg} / \mathrm{mL}$ was $96 \%$ (area under the curve (AUC) 0.91) [3]. The PRIDE study applying NT-proBNP levels showed similar findings among 600 patients presenting to the ED with dyspnea, in which the cut-off level was set at $300 \mathrm{pg} / \mathrm{mL}$, at $90 \%$ sensitivity and $85 \%$ specificity for the diagnosis of acute HF [1]. BNP is also useful for distinguishing between acute HF and acute respiratory deficiency syndrome (ARDS). In 80 ICU patients with acute hypoxemic respiratory failure, BNP offered good discriminatory performance for the diagnosis of ARDS or cardiogenic pulmonary edema (C-statistic, 0.80). At a cut-off point of $\leq 200 \mathrm{pg} / \mathrm{mL}$, BNP provided specificity of $91 \%$ for ARDS, whereas at a cut-off point of $\geq 1200 \mathrm{pg} / \mathrm{mL}$, BNP had a specificity of $92 \%$ for cardiogenic pulmonary edema [27].

\section{Diagnosis of Chronic Ambulatory HF}

BNP and NT-proBNP are useful in supporting or excluding the diagnosis of HF when the etiology of dyspnea is unclear. In a study including 250 patients with dyspnea, the BNP cut-off for the diagnosis of congestive $\mathrm{HF}$ was $80 \mathrm{pg} / \mathrm{mL}$ ( $95 \%$ accuracy), resulting in a satisfactory positive predictive value of $90 \%$ and negative predictive value of $98 \%$ [28]. In another study of 78 patients seen at a single HF clinic, BNP significantly increased according to different NYHA functional classes (class I: $21.6 \pm 2.8 \mathrm{pg} / \mathrm{mL}$, class II: $108.6 \pm 16.3 \mathrm{pg} / \mathrm{mL}$, class III: $197.1 \pm 27.2 \mathrm{pg} / \mathrm{mL}$, and class IV: $363.0 \pm 67.8 \mathrm{pg} / \mathrm{mL}, p<0.0001$ ). A cut-off value of $107.5 \mathrm{pg} / \mathrm{mL}$ (75th percentile) was a significant predictor of clinical events, for which the relative HR was 1.492 (95\% confidence interval (CI) 1.221-1.819) [29]. Using a cut-off of NT-proBNP of $125 \mathrm{pg} / \mathrm{mL}$ also had an excellent negative predictive power of $97 \%$ [2]. Because the mechanisms of chronic HF are more multifactorial with different underlying cardiac and non-cardiac diseases than those of acute HF, it may be difficult to determine a single cut-off value for the diagnosis of chronic HF. The ESC 2012 guideline mentioned that the sensitivity and specificity of BNP and NT-proBNP for the diagnosis of HF are lower in patients in the non-acute phase. The cut-off level of BNP for chronic HF was $35 \mathrm{pg} / \mathrm{mL}[30]$.

\section{HF with Preserved versus Reduced EF (HFpEF vs. HFrEF)}

Stretching of ventricular cardiomyocytes is the most important stimulus of BNP regulation [31], but LV diastolic wall stress also reflects an increased BNP [32]. Therefore, BNP can be used in the diagnosis of HFpEF. In 2042 community residents, the utility of BNP for the detection of diastolic dysfunction was limited, although that of BNP was valuable for the detection of systolic dysfunction [33]. In a comparison between HFrEF ( $\mathrm{EF} \leq 50 \%$ ) and HFpEF ( $\mathrm{EF}>50 \%$ ) in 160 consecutive patients presenting with $\mathrm{HF}$, the BNP level was significantly higher in those with HFrEF compared with those with HFpEF (267 (136-583) and 105 (64-146) pg/mL, respectively, $p<0.001$ ) [32]. The Breathing Not Properly Multinational Study was a seven-center, prospective study including 1586 patients who presented with acute dyspnea. Congestive HF was diagnosed in 452 patients. In those with HFpEF (EF $>45 \%$ ), BNP level was significantly lower than in those with HFrEF (413 vs. $821 \mathrm{pg} / \mathrm{mL}, p<0.001$ ) [34]. Similarly, 1670 patients from the Korean Heart Failure registry with $\operatorname{HFpEF}(\mathrm{EF} \geq 50 \%$ ) had significantly lower NT-proBNP levels than those with HFrEF (median 2723 vs. 5644 pg/mL, $p<0.001$ ) [35]. Although the use of BNP alone results in relatively poor detection of diastolic dysfunction, its combination with the echocardiographic value of diastolic dysfunction such as from pulsed-wave Doppler examination of the mitral flow (E/A) might help reinforce the diagnosis of diastolic dysfunction [36]. 


\section{Prognostication of HF}

Measurements of BNP and NT-proBNP are also useful in the prognostication of HF. In 452 ambulatory patients with reduced $\mathrm{EF}(<35 \%)$ with three-year follow-up, patients with a BNP level of $>130 \mathrm{pg} / \mathrm{mL}$ had a higher rate of sudden cardiac death [37]. The Rapid Emergency Department Heart Failure Outpatient Trial (REDHOT) study was a 10-center trial that included patients seen in the ED with shortness of breath. A BNP of $>200 \mathrm{pg} / \mathrm{mL}$ was strongly predictive of the 90 -day combined event rate (HF visits or admissions and mortality) [38]. In the large ADHERE (Acute Decompensated Heart Failure National Registry) study comprising 65,257 patients with acute decompensated HF, BNP at time of admission independently predicted in-hospital mortality [39]. In 599 patients with shortness of breath treated in the ED, the NT-proBNP cut-off point for predicting one-year mortality was $986 \mathrm{pg} / \mathrm{mL}$, and this cut-off value was the single strongest predictor of death at one year (HR, 2.88, 95\% CI, 1.64-5.06, $p<0.001)[40]$.

\section{Prognostication of ACS}

NPs are recognized as important predictors of cardiovascular events in patients with not only HF but also ACS. In 1996, Omland et al. published data of 131 patients with documented acute myocardial infarction. The median follow-up period was 1293 days, and BNP proved to be one of the powerful predictors of cardiovascular mortality (Cox regression of survival time, coefficient 0.69 , SE $0.22, p<0.001$ ) [41]. In total, 438 patients presenting within $6 \mathrm{~h}$ of the onset of ST-elevation myocardial infarction were enrolled in the ENTIRE-TIMI-23 trial. Outcomes were assessed through 30 days. BNP was higher in patients who died compared with survivors ( 89 vs. $15 \mathrm{pg} / \mathrm{mL}, p<0.0001)$. A BNP level of $80 \mathrm{pg} / \mathrm{mL}$ was associated with a seven-fold higher risk of mortality (odds ratio (OR), 7.2, 95\% CI, 2.1-24.5, $p=0.001$ ) [42]. Some studies showed that the prognostic value of BNP and NT-proBNP were superior to that of troponins. The adjusted ORs $(95 \% \mathrm{CI})$ for death at 10 months in the second, third, and fourth quartiles of BNP were 3.8 (1.1-13.3), 4.0 (1.2-13.7), and 5.8 (1.7-19.7), respectively [4]. For two-year mortality, the OR applied to a doubling of the NT-proBNP level, 800 vs. $400 \mathrm{pg} / \mathrm{mL}$, was 1.36 (1.04-1.76) [5]. Furthermore, the OR based on the NT-proBNP level at six months was higher than that at two days: 1.89 (1.14-3.14) vs. 1.29 (0.99-1.67). This suggested that the NT-proBNP level measured during a stable chronic phase is a better predictor of mortality than that measured during an acute phase [5].

\section{Interpretations of NP Levels in Different Populations}

Several factors increase the NP level: Renal dysfunction, age, and sex (female). Conversely obesity and flash pulmonary edema decrease NP level. Furthermore, NP levels differ substantially according to race/ethnicity.

In a reference sample of 911 healthy subjects (mean age 55 years, $62 \%$ women) from the Framingham Heart Study, the strongest predictors of higher NP levels were older age and female sex [43]. Similarly, in 2042 randomly selected community residents $>44$ years old, BNP increased significantly with age and was significantly higher in women than in men [44]. Framingham Study participants without HF were revealed to have mean BNP levels in lean $\left(<25 \mathrm{~kg} / \mathrm{m}^{2}\right)$, overweight $\left(25\right.$ to $\left.29.9 \mathrm{~kg} / \mathrm{m}^{2}\right)$, and obese $\left(\geq 30 \mathrm{~kg} / \mathrm{m}^{2}\right)$ men of 21.4, 15.5, and $12.7 \mathrm{pg} / \mathrm{mL}$, respectively (trend $p<0.0001$ ) [45]. In $318 \mathrm{HF}$ patients, levels of BNP were significantly lower in the obese than in the nonobese subjects ( $205 \pm 22 \mathrm{vs}$. $335 \pm 39 \mathrm{pg} / \mathrm{mL}, p=0.0007$ ), and multivariate regression analysis identified body mass index (BMI) as an independent negative correlate of BNP level [46]. In 1103 patients presenting to the ED with acute dyspnea, the NT-proBNP concentrations in the overweight and obese groups were significantly lower than that in the lean patients, regardless of the presence of acute HF $(p<0.001)$ [47]. There seemed to be a linear decrease in BNP levels with increasing BMI. In 316 systolic HF patients, the optimal BNP cut-off values for the prediction of death or urgent transplant in lean, overweight, and obese HF patients were 747,380 , and $332 \mathrm{pg} / \mathrm{mL}$, respectively [48]. In obese patients (BMI $>35 \mathrm{~kg} / \mathrm{m}^{2}$ ), a significantly lower 
BNP cut-off level $(<50 \mathrm{pg} / \mathrm{mL})$ should be used to rule out HF [48]. The reason for the lower BNP in obese patients remains unclear. On the contrary, cut-off values of NPs for patients with an extremely low BMI have not been evaluated.

The BNP cut-off point for the diagnosis of HF may need to be raised when the estimated glomerular filtration rate (eGFR) is $<60 \mathrm{~mL} / \mathrm{min} / 1.73 \mathrm{~m}^{2}$. The BNP level in patients with an eGFR $<60 \mathrm{~mL} / \mathrm{min} / 1.73 \mathrm{~m}^{2}$ was approximately two- to four-fold greater than that in patients with an eGFR $\geq 60 \mathrm{~mL} / \mathrm{min} / 1.73 \mathrm{~m}^{2}[49,50]$. In the Breathing Not Properly Multinational Study including 1586 participants who presented with acute dyspnea with an eGFR $<60 \mathrm{~mL} / \mathrm{min} / 1.73 \mathrm{~m}^{2}$, BNP was influenced by renal function. The optimum cut-off points for BNP were 70.7, 104.3, 201.2, and $225.0 \mathrm{pg} / \mathrm{mL}$ for the eGFR categories of $\geq 90,89$ to 60,59 to 30 , and $<30 \mathrm{~mL} / \mathrm{min} / 1.73 \mathrm{~m}^{2}$, respectively [51] (Figure 1).

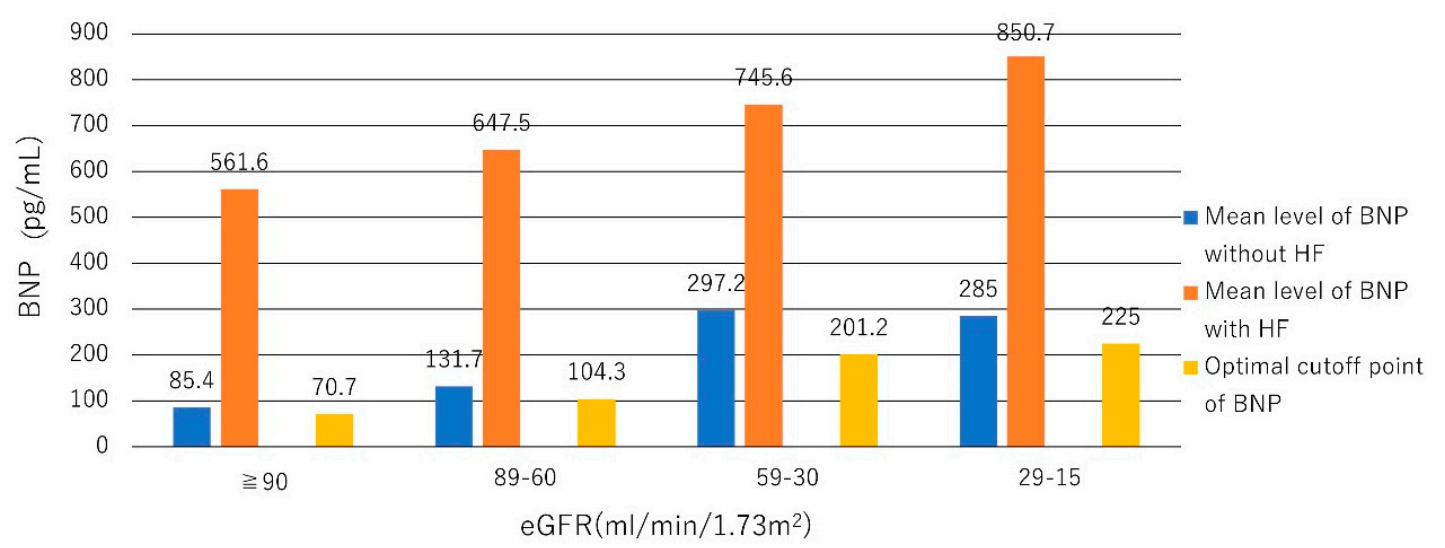

Figure 1. Correlations between B-type natriuretic peptide (BNP) and estimated glomerular filtration rate (eGFR) values. The level of BNP is influenced by renal function, especially when the eGFR is less than $60 \mathrm{~mL} / \mathrm{min} / 1.73 \mathrm{~m}^{2}$. The BNP cut-off points for the diagnosis of heart failure (HF) may need to be raised in renal dysfunction [51].

As mentioned above, BNP clearance is dependent on neutral endopeptidase, and NT-proBNP clearance is dependent on direct renal filtration [18]. Therefore, the NT-proBNP level would seem to be more affected by renal dysfunction than would BNP [52]. A multi-ethnic cohort study showed that NT-proBNP levels differ substantially according to race/ethnicity. NT-proBNP levels were lowest in black $(24 \mathrm{pg} / \mathrm{mL})$ as compared with white $(32 \mathrm{pg} / \mathrm{mL})$ and Hispanic $(30 \mathrm{pg} / \mathrm{mL})$ patients $(p<0.0001)$ [53]. Another study revealed a similar trend for black (median $43 \mathrm{pg} / \mathrm{mL}$ ), Chinese $(43 \mathrm{pg} / \mathrm{mL}$ ), Hispanic $(53 \mathrm{pg} / \mathrm{mL})$, and white $(68 \mathrm{pg} / \mathrm{mL})$ patients $(p=0.0001)[54]$.

\section{NP-Guided Therapy}

NP can help in the clinical management of HF. Several studies have shown the utility of NP-guided therapy. In the 2013 ACCF/AHA guideline, BNP (or NT-proBNP)-guided therapy is placed in the category of Class IIa, evidence level of B [24]. In a STARS-BNP trial including 220 patients with HF with New York Heart Association functional class II to III, patients were randomized to receive BNP-guided treatment with a goal of BNP levels of $<100 \mathrm{pg} / \mathrm{mL}$ for the BNP group. At the end of the first three months, the mean dosages of angiotensin-converting enzyme inhibitors and beta-blockers were significantly higher in the BNP group $(p<0.05)$. By 15 months of follow-up, patients in the BNP-guided treatment group had a significantly lower number of events of HF-related death or readmission than the patients treated according to current guidelines $(24 \%$ vs. $52 \%, p<0.001)$ [55]. Similar effectiveness was also proved in the BATTLESCARRED trial using NT-proBNP-guided therapy in which 364 patients with HF admitted to a single hospital were randomly allocated 1:1:1 (stratified by age) to therapy guided by NT-proBNP levels or by intensive clinical management or according to usual care. Treatment strategies were applied for two years with a follow-up of three years. One-year mortality was less 
in both the NT-proBNP (9.1\%) and clinically guided (9.1\%) groups compared with the usual care group $(18.9 \%, p=0.03)$. Three-year mortality was selectively reduced in patients $\leq 75$ years of age receiving NT-proBNP-guided treatment (15.5\%) compared with their peers receiving either clinically managed treatment $(30.9 \%, p=0.048)$ or usual care $(31.3 \%, p=0.021)$ [56]. Conversely, BNP-guided therapy may be harmful in patients with HFpEF. In HFrEF patients, NT-pro or BNP-guided therapy compared with symptom-guided therapy resulted in lower mortality (HR, 0.78, 95\% CI, 0.62-0.97, $p=0.03$ ) and fewer HF admissions (HR, 0.80, 95\% CI, 0.67-0.97, $p=0.02$ ), whereas in HFpEF patients, renal failure provided the strongest interaction. Increased risk of (NT-pro) BNP-guided therapy was observed if renal failure was present $(p<0.01)$, and (NT-pro) BNP-guided therapy was beneficial only if none or one of the comorbidities, such as chronic obstructive pulmonary disease, diabetes, cardiovascular insult, or peripheral vascular disease, was present $(p<0.01)$. Additionally, (NT-pro) BNP-guided therapy may be inappropriate in HFpEF patients without hypertension ( $p=0.02)$ [57]. Moreover, in elderly HF patients in the TIME-CHF trial, NT-proBNP-guided therapy resulted in a higher rate of survival and a lower rate of all-cause hospitalization in patients aged 60 to 70 years, but not in patients older than 75 years, by 18 months of follow-up after initial admission [58]. Taken together, in elderly and HFpEF patients, NP guided-therapy may not be beneficial compared with symptom-guided medication.

\section{Mid-Regional proANP}

ProANP is a polypeptide comprising 126 amino acids, with ANP consisting of amino acids 99-126. The N-terminal portion of proANP, termed proANP1-98 or NT-proANP, has a much longer half-life than ANP and has therefore been suggested to be a more reliable analyte for measurement than ANP. ProANP1-98 can be subjected to further fragmentation, and an immunoassay for mid-regional (MR) proANP (amino acids 53-90) was developed to measure the proANP level. In 325 healthy individuals, the range of MR-proANP was 9.6-313 pmol/L, and the median was $45 \mathrm{pmol} / \mathrm{L}$ [59].

The largest study to evaluate MR-proANP for the diagnosis of acute HF, the BACH (Biomarkers in Acute Heart Failure) trial, was a prospective, 15-center, international study including 1641 patients presenting to the ED with dyspnea. MR-proANP ( $\geq 120 \mathrm{pmol} / \mathrm{L})$ provided a sensitivity of $97 \%$, a negative predictive value of $97.4 \%$, and AUC of 0.90 that proved noninferior to BNP $(\geq 100 \mathrm{pg} / \mathrm{mL})$ for the diagnosis of acute HF (accuracy difference 0.9\%) [60]. Other studies have shown similar findings [61,62]. MR-proANP also has prognostic utility in acute HF and chronic HF. Although the utility of MR-proANP to diagnose acute HF was lower than that of BNP and NT-pro BNP (AUC 0.901 vs. 0.973 vs. 0.922 , respectively), MR-proANP had better prognostic value for mortality than did BNP (AUC 0.668 vs. 0.604 ) at five years [63] (Figure 2).

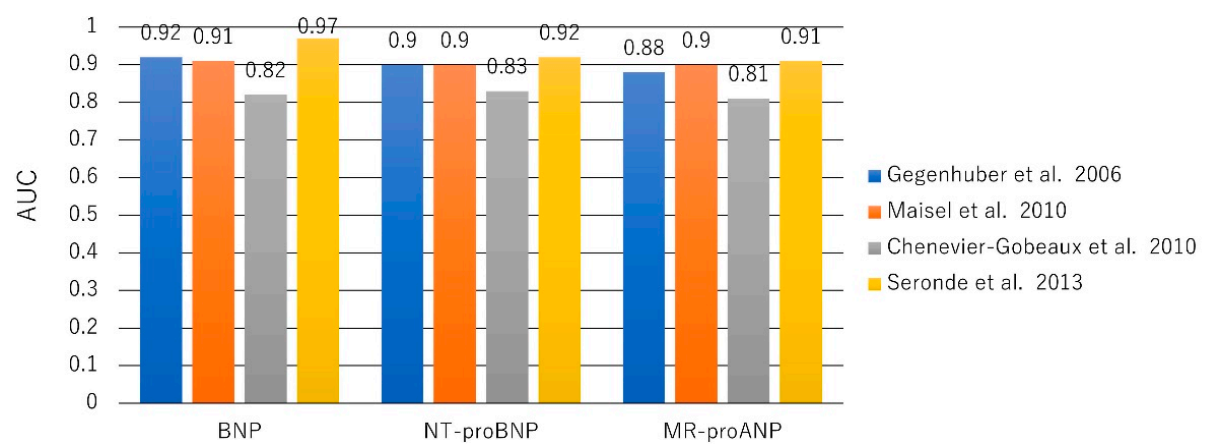

Figure 2. Area under the curve (AUC) for NP to diagnose acute HF. Similar values of BNP, NT-proBNP, and MR-proANP for diagnosis of acute HF [60-63].

In the GISSI-HF trial including 1237 patients with chronic and stable HF, MR-proANP and NT-pro BNP were measured at randomization and after three months. Changes in MR-proANP concentrations were related to mortality, whereas changes in NT-proBNP markers were not [64]. 
Moreover, MR-proANP may have utility as a screening tool in community populations. Although NT-proBNP and MR-proANP predicted incident HF during 14 months of follow-up, only MR-proANP predicted incident AF [65]. Similar to those of BNP and NT-proBNP, the level of MR-pro ANP is increased with age, decreased by a higher BMI, and influenced by race and sex [66].

\section{AF and NPs}

ANP is synthesized and secreted mainly by atrial cardiomyocytes in response to atrial dilatation, whereas BNP is produced chiefly in the ventricular myocardium in response to ventricular stretch and pressure overload [67]. In some patients in AF without HF, the level of ANP was normal, but that of BNP or NT-proBNP was elevated $[6,68]$. The reason for the elevated BNP and NT-proBNP levels was suggested to be due to the small amount of BNP that is also produced and secreted by atrial tissue [69]. Atrial dysrhythmia would also increase BNP secretion [70,71]. Asynchronous contraction of the atrial myocardium could produce a tethering effect of atrial myocardial fibers that may stimulate the secretion of BNP [71]. Furthermore, during AF, the elevated atrial pressure stretches the atrial wall (pressure overload), and loss of atrial contraction leads to an unfavorable alternation of the left ventricular filling pattern [72]. BNP decreased significantly $24 \mathrm{~h}$ after the restoration of sinus rhythm (SR) by cardioversion in patients with paroxysmal and persistent AF (from 95 to $28 \mathrm{pg} / \mathrm{mL}$ in paroxysmal AF and from 75 to $41 \mathrm{pg} / \mathrm{mL}$ in persistent $\mathrm{AF}$ ) [73,74].

BNP is a more valuable marker for the diagnosis of LV diastolic function compared to ANP. Bakowski et al. investigated 42 patients with AF in whom SR was restored by cardioversion and maintained for at least 30 days. The average values of ANP during AF in patients with normal and impaired diastolic function were $167.3 \pm 70.1$ and $298.7 \pm 83.6 \mathrm{pg} / \mathrm{mL}$, respectively $(p<0.001)$, and those of BNP were $49.5 \pm 14.7$ and $145.6 \pm 49.6 \mathrm{pg} / \mathrm{mL}$, respectively $(p<0.001)$. An ANP value $>220.7 \mathrm{pg} / \mathrm{mL}$ measured during AF identified patients with impaired LV diastolic function with $85 \%$ sensitivity and $90 \%$ specificity. A BNP value of $>74.7 \mathrm{pg} / \mathrm{mL}$ proved to be $95 \%$ sensitive and $100 \%$ specific in the diagnosis of such patients [75]. BNP was a more specific and sensitive marker of impaired LV diastolic function than was ANP.

\section{Incident AF in Community Studies}

Some studies showed elevated BNP and NT-proBNP levels to be associated with increased AF incidence $[9,26,76,77]$. In three US community-based studies (ARIC, CHS, and FHS), including 18,556 participants overall, BNP and CRP were positively associated with AF incidence [78]. That finding was similar in the elderly population. In a community-based population of 5445 older patients in the Cardiovascular Health Study, NT-proBNP levels were strongly associated with prevalent AF. After a median follow-up of 10 years, the incidence of AF was 2.2 per 100 person-years [7]. Although BNP and NT-proBNP levels were highly predictive of incident AF, the cut-off levels were unclear. In the Framingham cohort, the correlation of NT-proANP with BNP was moderately high at 0.66 , and after incorporation of both natriuretic peptides into the model, BNP emerged as the stronger biomarker [76].

\section{Impact of Structural Heart Disease in AF patients}

The cut-off level of NP to detect structural heart disease is different between SR and AF. In 793 patients with structural heart disease at a single center, NT-proBNP levels were 960 (IQR 359-2625) pg/mL for SR $(n=591)$ and $2491(1443-4368) \mathrm{pg} / \mathrm{mL}$ for AF $(n=202)(p<0.001)$. The areas under the ROC curve for NT-proBNP to detect structural heart disease were 0.79 for SR $(95 \% \mathrm{CI}, 0.77-0.82)$ and 0.78 for AF (95\% CI, 0.72-0.84). NT-proBNP cut-off levels necessary to achieve a 1-in-100 false-negative rate were 27.5 (7.5-30.5) pg/mL for SR and 524 (253-662) pg/mL for AF [79]. 


\section{HF and AF}

Both AF and HF increase BNP and NT-proBNP levels, but these levels remain useful in the diagnosis of HF in patients with AF. In the PRIDE study, 600 patients presented to the ED with acute dyspnea. AF was associated with higher NT-proBNP in the dyspneic patients and particularly in those without acute HF [80]. The BASEL study randomly assigned 452 patients with AF and dyspnea to a diagnostic strategy with or without the use of BNP. BNP cut-off levels of 100 and $500 \mathrm{pg} / \mathrm{mL}$ for the diagnosis of HF were determined. If BNP was $<100 \mathrm{pg} / \mathrm{mL}, \mathrm{HF}$ was considered unlikely, whereas if BNP was $>500 \mathrm{pg} / \mathrm{mL}$, HF was considered likely. The use of BNP significantly reduced time to discharge (median eight days in the BNP group vs. 12 days in the control group, $p=0.046$ ) and time to initiation of adequate therapy (median $51 \mathrm{~min}$ in the BNP group vs. $100 \mathrm{~min}$ in the control group, $p=0.024$ ) [8]. In patients with both HF and AF, the higher cut-off levels of BNP and NT-proBNP should be used. The BACH study including 1445 patients with acute dyspnea showed that the diagnostic performance of BNP and NT-proBNP for acute HF was impaired by the presence of AF [81] (Figure 3).

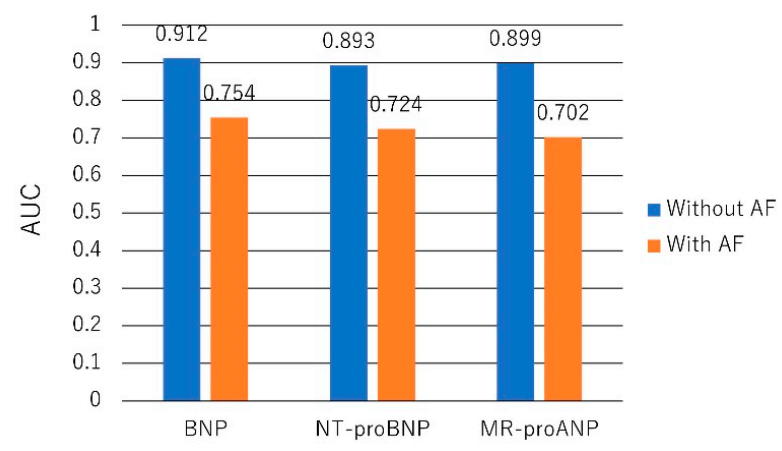

Figure 3. AUC for NP to diagnose acute HF in atrial fibrillation (AF). AUCs for BNP, NT-proBNP, and MR-proANP to diagnose acute HF are similarly reduced in the presence of AF [81].

Among 1431 patients without HF, permanent/paroxysmal AF was associated with significantly higher BNP levels $(p=0.001)$. Conversely, in patients with HF, BNP levels did not differ significantly between patients with and without AF $(p=0.533)$. A BNP cut-off value of $100 \mathrm{pg} / \mathrm{mL}$ had respective specificities of $40 \%$ and $79 \%$ for the diagnosis of acute HF in patients with and without AF. In patients with AF, a cut-off level of $200 \mathrm{pg} / \mathrm{mL}$ resulted in a marked improvement in specificity and positive likelihood ratio for diagnosing HF compared with the conventional cut-off level of $100 \mathrm{pg} / \mathrm{mL}$, with little loss of sensitivity [82]. Another study showed that the BNP cut-off level for HF that maintained high sensitivity was $150 \mathrm{pg} / \mathrm{mL}$ for those with AF [83] (Figure 4).

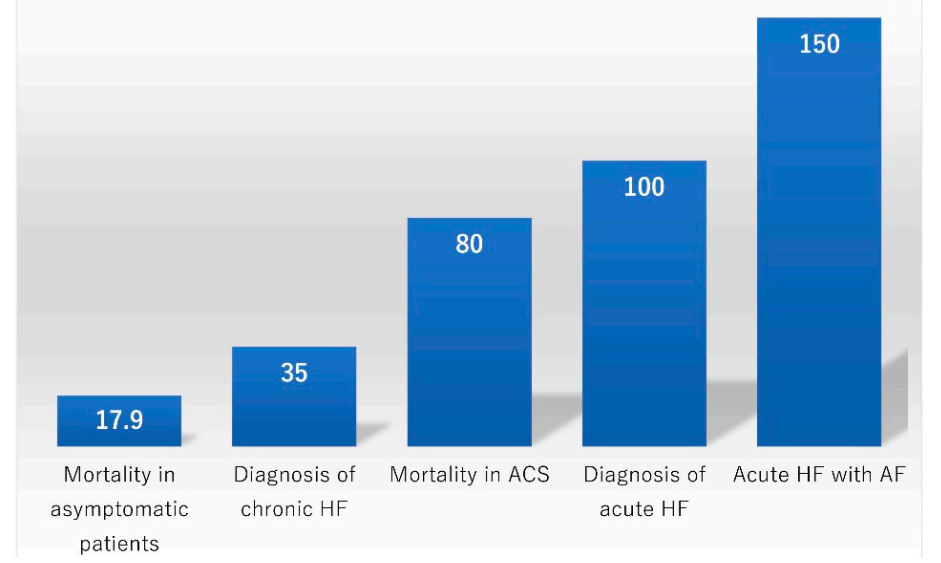

Figure 4. Cut-off points of BNP (pg/mL). The cut-off points of BNP vary among clinical settings [1-3,25, 30,42,83]. ACS: Acute coronary syndrome. 
Similarly, in 1941 elderly community-dwelling residents, NT-proBNP levels of patients with AF with and without HF were $744 \mathrm{pg} / \mathrm{mL}$ and $211 \mathrm{pg} / \mathrm{mL}$, respectively. At the cut-off point of $125 \mathrm{pg} / \mathrm{mL}$, sensitivity and specificity were $93 \%$ and $35 \%$, respectively, and positive and negative predictive values were $51 \%$ and $86 \%$, respectively [84].

NT-proBNP had a predictive value for adverse cardiovascular outcomes irrespective of AF status. In a large trial including 14,737 patients with HFrEF, NT-proBNP was associated with a risk of cardiovascular death or hospitalization for HF with and without AF. However, when the NT-proBNP level was $>400 \mathrm{pg} / \mathrm{mL}$, NT-proBNP had similar predictive value for adverse cardiovascular outcomes in patients with or without AF [85]. Even in patients with AF, BNP, and NT-proBNP are useful for the diagnosis and prediction of prognosis in patients with HF although their cut-off values should be offset.

\section{AF Recurrence after Cardioversion or Pulmonary Vein Isolation}

Baseline BNP and NT-proBNP values were found to be independent predictors for AF recurrence after cardioversion [86-88], but the cut-off levels differed between studies. Solheim et al. reported that at baseline, there were no differences in NT-proBNP levels ( $33.5 \mathrm{vs.} 29.5 \mathrm{pmol} / \mathrm{L}, p=0.9$ ) between patients with $\mathrm{AF}$ recurrence and nonrecurrence after ablation. At long-term follow-up, there was a marked decrease in the NT-proBNP level at $22 \pm 5$ months after ablation in the successful ablation patients $(7.0$ vs. $17.5 \mathrm{pmol} / \mathrm{L}, p<0.05)$. NT-proBNP correlated with LA volume both at baseline $(r=0.71$, $p<0.001)$ and at follow-up $(r=0.57, p<0.001)$. AF burden correlated with both NT-proBNP $(r=0.47$, $p<0.01)$ and LA volume $(r=0.52, p<0.01)$. A decrease in NT-pro-BNP of $>25 \%$ from the baseline value could be useful as a marker of ablation success [89]. A meta-analysis of electronic databases including 10 studies suggested that both increased baseline BNP and NT-pro BNP levels, are associated with greater risk of AF recurrence after catheter ablation [90]. In another meta-analysis of 36 studies, compared with the nonrecurrence group, the recurrence group had increased pre-ablation levels of ANP, BNP, and NT-pro-BNP (standardized mean difference (95\% CI): 0.37 (0.13-0.61), 0.77 (0.40-1.14), and $1.25(0.64-1.87)$ ) [91]. Deng et al. evaluated 1410 consecutive AF patients ( $68 \%$ male, $57.2 \pm 11.6$ years) undergoing AF ablation, during a mean follow-up of $20.7 \pm 8.8$ months. The cut-off value of BNP for AF recurrence was $237.45 \mathrm{pg} / \mathrm{mL}$. Similar findings were evident in the subgroups of patients with paroxysmal or nonparoxysmal AF [92]. The NT-proBNP level at baseline was an independent predictor of AF recurrence $(p<0.001)$ after pulmonary vein isolation with a cut-off value of NT-proBNP of $\geq 423.2 \mathrm{pg} / \mathrm{mL}(p=0.002)[68]$.

\section{Stroke in AF Patients}

BNP and NT-proBNP are also independent risk markers of stroke in AF patients. Anticoagulated AF patients with a high NT-proBNP level were associated with an increased risk of stroke $[93,94]$. In the RE-LY trial including 6189 patients, rates of stroke were independently related to levels of NT-proBNP ( $2.30 \%$ /year vs. $0.92 \% /$ year in the highest $(>1402 \mathrm{pg} / \mathrm{mL})$ versus lowest $(<387 \mathrm{pg} / \mathrm{mL})$ quartile groups, HR, 2.40 (95\% CI, 1.41-4.07), $p=0.0014$ ) [94]. The biomarker-based ABC stroke score (age, biomarkers, and clinical history of prior stroke) was recently shown to improve the prediction of stroke risk in patients with AF. In the ARISTOTLE trial including 18,201 patients with AF, adding NT-proBNP levels to the CHA2DS2-VASc score improved the C-statistic from 0.62 to $0.65(p=0.0009)$ for stroke or systemic embolism and from 0.59 to 0.69 for cardiac death $(p<0.0001)$ [95]. The biomarker-based $\mathrm{ABC}$ stroke score performed better than presently used scores such as the CHA2DS2-VASc and ATRIA scores $[96,97]$.

\section{MR-proANP in AF Patients}

Due to the short half-life and lability of ANP, BNP is preferred for the diagnosis and management of AF. ANP is primarily a feature of atrial cardiomyocytes and may thus be a more appropriate biological marker of atrial changes. The more stable MR-proANP level may be more useful for the 
assessment of AF. In 632 consecutive patients presenting with acute dyspnea, the diagnostic accuracy of acute HF in AF patients was similar for MR-proANP (0.90, 95\% CI 0.84-0.95) and NT-proBNP $(0.89,95 \%$ CI $0.81-0.96)$. MR-proANP strongly predicted one-year all-cause mortality (HR $=1.13$ (1.09-1.17), per 100 pmol/L increase, $p<0.001$ ) [98]. However, in the AMIO-CAT trial evaluating patients undergoing ablation for $\mathrm{AF}$, patients with persistent $\mathrm{AF}$ had higher concentrations of both MR-proANP and NT-proBNP at baseline than those with paroxysmal AF. The NT-proBNP level was significantly associated with the incidence of documented AF/AT recurrence within the three-month blanking period after catheter ablation (HR, 1.84, 95\% CI, 1.06-3.19, $p=0.030)$, but the MR-proANP level was not (HR, 2.87, 95\% CI, 0.86-9.50, $p=0.085)$. The baseline MR-proANP and NT-proBNP levels were not associated with the recurrence of AF at six months after ablation (MR-proANP: OR, 4.40, 95\% CI, 0.57-33.71, $p=0.15$ and NT-proBNP: OR, 1.42, 95\% CI, 0.59-3.41, $p=0.15$ ) [99]. It is still unclear which is superior for AF management, MR-proANP, or NT-proBNP.

\section{Depletion of ANP in AF Patients with Atrial Remodeling}

Because the secretion of ANP is induced by stretching of the atrial wall, ANP is depleted in the atrium with advanced fibrosis, which leads to reduced ANP production capacity [100]. When AF converts to the longstanding form, the atria are characterized by a loss of myocytes and an increase in fibrous tissue $[101,102]$. Histological examination showed that in patients undergoing the maze procedure, preoperative ANP was significantly lower in the AF group than in the SR group. In the AF group, the messenger RNA expressions of ANP were lower, and collagen volumes were higher than those in the SR group [103]. Yoshida et al. reported that in patients with persistent AF and an enlarged LA undergoing ablation, the reduction of LA volume after ablation was greater in patients with a higher ANP level (73 vs. $50 \mathrm{pg} / \mathrm{mL}, p=0.02$ ). This finding indicated a relation between healthy atrial myocardium and preserved ANP secretion [104]. This hypothesis that ANP can serve as a marker of atrial integrity was further supported by another study performing longitudinal assessments of left atrial volume with cardiac computed tomography in patients with AF [105]. Yoshida et al. also proposed the original index ANP/BNP ratio, which may be more sensitive to a heart condition and better reflects atrial integrity than ANP or BNP alone. Patients with more severe HF (higher BNP) and more advanced atrial fibrosis (lower ANP) have a much lower ANP/BNP ratio than those without these conditions [106]. However, this interpretation of the ANP/BNP ratio needs validation in future studies, and assessment of the $M R$-proANP/BNP ratio is also of interest with respect to atrial remodeling in patients with $\mathrm{HF}$ and AF.

\section{Conclusions}

NP levels can greatly help in the clinical management of cardiovascular diseases. In patients with HF, NP has been established as a tool of diagnosis and prognostication, a guide to the management and monitoring of therapy, and a surrogate of the underlying disease and cut-off levels have been confirmed. Although NP is also useful for AF management, such as in screening for the new onset of incident $\mathrm{AF}$ and in predicting the success of cardioversions and pulmonary vein isolation, and the risk of stroke, we hope that further applications of NPs, particularly MR-proANP, to patients with AF will contribute to clarifying the complex mechanisms of AF.

Funding: This research received no external funding.

Conflicts of Interest: The authors declare no conflict of interest. 


\section{References}

1. Januzzi, J.L., Jr.; Camargo, C.A.; Anwaruddin, S.; Baggish, A.L.; Chen, A.A.; Krauser, D.G.; Tung, R.; Cameron, R.; Nagurney, J.T.; Chae, C.U.; et al. The N-terminal Pro-BNP investigation of dyspnea in the emergency department (PRIDE) study. Am. J. Cardiol. 2005, 95, 948-954. [CrossRef] [PubMed]

2. Hildebrandt, P.; Collinson, P.O. Amino-terminal pro-B-type natriuretic peptide testing to assist the diagnostic evaluation of heart failure in symptomatic primary care patients. Am. J. Cardiol. 2008, 101, 25-28. [CrossRef]

3. Maisel, A.S.; Krishnaswamy, P.; Nowak, R.M.; McCord, J.; Hollander, J.E.; Duc, P.; Omland, T.; Storrow, A.B.; Abraham, W.T.; Wu, A.H.; et al. Rapid measurement of B-type natriuretic peptide in the emergency diagnosis of heart failure. N. Engl. J. Med. 2002, 347, 161-167. [CrossRef] [PubMed]

4. de Lemos, J.A.; Morrow, D.A.; Bentley, J.H.; Omland, T.; Sabatine, M.S.; McCabe, C.H.; Hall, C.; Cannon, C.P.; Braunwald, E. The prognostic value of B-type natriuretic peptide in patients with acute coronary syndromes. N. Engl. J. Med. 2001, 345, 1014-1021. [CrossRef] [PubMed]

5. Lindahl, B.; Lindback, J.; Jernberg, T.; Johnston, N.; Stridsberg, M.; Venge, P.; Wallentin, L. Serial analyses of N-terminal pro-B-type natriuretic peptide in patients with non-ST-segment elevation acute coronary syndromes: A Fragmin and fast Revascularisation during In Stability in Coronary artery disease (FRISC)-II substudy. J. Am. Coll. Cardiol. 2005, 45, 533-541. [CrossRef] [PubMed]

6. Ellinor, P.T.; Low, A.F.; Patton, K.K.; Shea, M.A.; Macrae, C.A. Discordant atrial natriuretic peptide and brain natriuretic peptide levels in lone atrial fibrillation. J. Am. Coll. Cardiol. 2005, 45, 82-86. [CrossRef] [PubMed]

7. Patton, K.K.; Ellinor, P.T.; Heckbert, S.R.; Christenson, R.H.; DeFilippi, C.; Gottdiener, J.S.; Kronmal, R.A. $\mathrm{N}$-terminal pro-B-type natriuretic peptide is a major predictor of the development of atrial fibrillation: The Cardiovascular Health Study. Circulation 2009, 120, 1768-1774. [CrossRef]

8. Breidthardt, T.; Noveanu, M.; Cayir, S.; Viglino, M.; Laule, K.; Hochholzer, W.; Reichlin, T.; Potocki, M.; Christ, M.; Mueller, C. The use of B-type natriuretic peptide in the management of patients with atrial fibrillation and dyspnea. Int. J. Cardiol. 2009, 136, 193-199. [CrossRef]

9. Patton, K.K.; Heckbert, S.R.; Alonso, A.; Bahrami, H.; Lima, J.A.; Burke, G.; Kronmal, R.A. N-terminal pro-B-type natriuretic peptide as a predictor of incident atrial fibrillation in the Multi-Ethnic Study of Atherosclerosis: The effects of age, sex and ethnicity. Heart 2013, 99, 1832-1836. [CrossRef]

10. Kirchhof, P.; Benussi, S.; Kotecha, D.; Ahlsson, A.; Atar, D.; Casadei, B.; Castella, M.; Diener, H.C.; Heidbuchel, H.; Hendriks, J.; et al. 2016 ESC Guidelines for the management of atrial fibrillation developed in collaboration with EACTS. Europace 2016, 18, 1609-1678. [CrossRef]

11. Edwards, B.S.; Zimmerman, R.S.; Schwab, T.R.; Heublein, D.M.; Burnett, J.C., Jr. Atrial stretch, not pressure, is the principal determinant controlling the acute release of atrial natriuretic factor. Circ. Res. 1988, 62, 191-195. [CrossRef] [PubMed]

12. Cody, R.J.; Atlas, S.A.; Laragh, J.H.; Kubo, S.H.; Covit, A.B.; Ryman, K.S.; Shaknovich, A.; Pondolfino, K.; Clark, M.; Camargo, M.J.; et al. Atrial natriuretic factor in normal subjects and heart failure patients. Plasma levels and renal, hormonal, and hemodynamic responses to peptide infusion. J. Clin. Investig. 1986, 78, 1362-1374. [CrossRef] [PubMed]

13. Nakao, K.; Sugawara, A.; Morii, N.; Sakamoto, M.; Yamada, T.; Itoh, H.; Shiono, S.; Saito, Y.; Nishimura, K.; Ban, T.; et al. The pharmacokinetics of alpha-human atrial natriuretic polypeptide in healthy subjects. Eur. J. Clin. Pharmacol. 1986, 31, 101-103. [CrossRef] [PubMed]

14. Hollister, A.S.; Rodeheffer, R.J.; White, F.J.; Potts, J.R.; Imada, T.; Inagami, T. Clearance of atrial natriuretic factor by lung, liver, and kidney in human subjects and the dog. J. Clin. Investig. 1989, 83, 623-628. [CrossRef] [PubMed]

15. Hall, C. Essential biochemistry and physiology of (NT-pro)BNP. Eur. J. Heart Fail. 2004, 6, 257-260. [CrossRef] [PubMed]

16. Abassi, Z.; Karram, T.; Ellaham, S.; Winaver, J.; Hoffman, A. Implications of the natriuretic peptide system in the pathogenesis of heart failure: Diagnostic and therapeutic importance. Pharmacol. Ther. 2004, 102, 223-241. [CrossRef] [PubMed]

17. Mukoyama, M.; Nakao, K.; Hosoda, K.; Suga, S.; Saito, Y.; Ogawa, Y.; Shirakami, G.; Jougasaki, M.; Obata, K.; Yasue, H.; et al. Brain natriuretic peptide as a novel cardiac hormone in humans. Evidence for an exquisite dual natriuretic peptide system, atrial natriuretic peptide and brain natriuretic peptide. J. Clin. Investig. 1991, 87, 1402-1412. [CrossRef] [PubMed] 
18. Daniels, L.B.; Maisel, A.S. Natriuretic peptides. J. Am. Coll. Cardiol. 2007, 50, 2357-2368. [CrossRef] [PubMed]

19. Lerman, A.; Gibbons, R.J.; Rodeheffer, R.J.; Bailey, K.R.; McKinley, L.J.; Heublein, D.M.; Burnett, J.C., Jr. Circulating N-terminal atrial natriuretic peptide as a marker for symptomless left-ventricular dysfunction. Lancet 1993, 341, 1105-1109. [CrossRef]

20. Tsutamoto, T.; Wada, A.; Maeda, K.; Hisanaga, T.; Maeda, Y.; Fukai, D.; Ohnishi, M.; Sugimoto, Y.; Kinoshita, M. Attenuation of compensation of endogenous cardiac natriuretic peptide system in chronic heart failure: Prognostic role of plasma brain natriuretic peptide concentration in patients with chronic symptomatic left ventricular dysfunction. Circulation 1997, 96, 509-516. [CrossRef]

21. Mukoyama, M.; Nakao, K.; Saito, Y.; Ogawa, Y.; Hosoda, K.; Suga, S.; Shirakami, G.; Jougasaki, M.; Imura, H. Human brain natriuretic peptide, a novel cardiac hormone. Lancet 1990, 335, 801-802. [CrossRef]

22. Mukoyama, M.; Nakao, K.; Saito, Y.; Ogawa, Y.; Hosoda, K.; Suga, S.; Shirakami, G.; Jougasaki, M.; Imura, H. Increased human brain natriuretic peptide in congestive heart failure. N. Engl. J. Med. 1990, 323, 757-758. [PubMed]

23. Ponikowski, P.; Voors, A.A.; Anker, S.D.; Bueno, H.; Cleland, J.G.F.; Coats, A.J.S.; Falk, V.; Gonzalez-Juanatey, J.R.; Harjola, V.P.; Jankowska, E.A.; et al. 2016 ESC Guidelines for the diagnosis and treatment of acute and chronic heart failure: The Task Force for the diagnosis and treatment of acute and chronic heart failure of the European Society of Cardiology (ESC)Developed with the special contribution of the Heart Failure Association (HFA) of the ESC. Eur. Heart J. 2016, 37, 2129-2200. [PubMed]

24. Yancy, C.W.; Jessup, M.; Bozkurt, B.; Butler, J.; Casey, D.E., Jr.; Drazner, M.H.; Fonarow, G.C.; Geraci, S.A.; Horwich, T.; Januzzi, J.L.; et al. 2013 ACCF/AHA guideline for the management of heart failure: A report of the American College of Cardiology Foundation/American Heart Association Task Force on Practice Guidelines. J. Am. Coll. Cardiol. 2013, 62, e147-e239. [CrossRef]

25. McDonagh, T.A.; Cunningham, A.D.; Morrison, C.E.; McMurray, J.J.; Ford, I.; Morton, J.J.; Dargie, H.J. Left ventricular dysfunction, natriuretic peptides, and mortality in an urban population. Heart 2001, 86, 21-26. [CrossRef] [PubMed]

26. Wang, T.J.; Larson, M.G.; Levy, D.; Benjamin, E.J.; Leip, E.P.; Omland, T.; Wolf, P.A.; Vasan, R.S. Plasma natriuretic peptide levels and the risk of cardiovascular events and death. N. Engl. J. Med. 2004, 350, 655-663. [CrossRef] [PubMed]

27. Karmpaliotis, D.; Kirtane, A.J.; Ruisi, C.P.; Polonsky, T.; Malhotra, A.; Talmor, D.; Kosmidou, I.; Jarolim, P.; de Lemos, J.A.; Sabatine, M.S.; et al. Diagnostic and prognostic utility of brain natriuretic Peptide in subjects admitted to the ICU with hypoxic respiratory failure due to noncardiogenic and cardiogenic pulmonary edema. Chest 2007, 131, 964-971. [CrossRef] [PubMed]

28. Dao, Q.; Krishnaswamy, P.; Kazanegra, R.; Harrison, A.; Amirnovin, R.; Lenert, L.; Clopton, P.; Alberto, J.; Hlavin, P.; Maisel, A.S. Utility of B-type natriuretic peptide in the diagnosis of congestive heart failure in an urgent-care setting. J. Am. Coll. Cardiol. 2001, 37, 379-385. [CrossRef]

29. Koglin, J.; Pehlivanli, S.; Schwaiblmair, M.; Vogeser, M.; Cremer, P.; vonScheidt, W. Role of brain natriuretic peptide in risk stratification of patients with congestive heart failure. J. Am. Coll. Cardiol. 2001, 38, 1934-1941. [CrossRef]

30. McMurray, J.J.; Adamopoulos, S.; Anker, S.D.; Auricchio, A.; Bohm, M.; Dickstein, K.; Falk, V.; Filippatos, G.; Fonseca, C.; Gomez-Sanchez, M.A.; et al. ESC Guidelines for the diagnosis and treatment of acute and chronic heart failure 2012: The Task Force for the Diagnosis and Treatment of Acute and Chronic Heart Failure 2012 of the European Society of Cardiology. Developed in collaboration with the Heart Failure Association (HFA) of the ESC. Eur. Heart J. 2012, 33, 1787-1847.

31. Tokola, H.; Hautala, N.; Marttila, M.; Magga, J.; Pikkarainen, S.; Kerkela, R.; Vuolteenaho, O.; Ruskoaho, H. Mechanical load-induced alterations in B-type natriuretic peptide gene expression. Can. J. Physiol. Pharmacol. 2001, 79, 646-653. [CrossRef] [PubMed]

32. Iwanaga, Y.; Nishi, I.; Furuichi, S.; Noguchi, T.; Sase, K.; Kihara, Y.; Goto, Y.; Nonogi, H. B-type natriuretic peptide strongly reflects diastolic wall stress in patients with chronic heart failure: Comparison between systolic and diastolic heart failure. J. Am. Coll. Cardiol. 2006, 47, 742-748. [CrossRef] [PubMed]

33. Redfield, M.M.; Rodeheffer, R.J.; Jacobsen, S.J.; Mahoney, D.W.; Bailey, K.R.; Burnett, J.C., Jr. Plasma brain natriuretic peptide to detect preclinical ventricular systolic or diastolic dysfunction: A community-based study. Circulation 2004, 109, 3176-3181. [CrossRef] [PubMed] 
34. Maisel, A.S.; McCord, J.; Nowak, R.M.; Hollander, J.E.; Wu, A.H.B.; Duc, P.; Omland, T.; Storrow, A.B.; Krishnaswamy, P.; Abraham, W.T.; et al. Bedside B-Type natriuretic peptide in the emergency diagnosis of heart failure with reduced or preserved ejection fraction. J. Am. Coll. Cardiol. 2003, 41, 2010-2017. [CrossRef]

35. Kang, S.H.; Park, J.J.; Choi, D.J.; Yoon, C.H.; Oh, I.Y.; Kang, S.M.; Yoo, B.S.; Jeon, E.S.; Kim, J.J.; Cho, M.C.; et al. Prognostic value of NT-proBNP in heart failure with preserved versus reduced EF. Heart 2015, 101, 1881-1888. [CrossRef]

36. Lubien, E.; DeMaria, A.; Krishnaswamy, P.; Clopton, P.; Koon, J.; Kazanegra, R.; Gardetto, N.; Wanner, E.; Maisel, A.S. Utility of B-natriuretic peptide in detecting diastolic dysfunction: Comparison with Doppler velocity recordings. Circulation 2002, 105, 595-601. [CrossRef]

37. Berger, R.; Huelsman, M.; Strecker, K.; Bojic, A.; Moser, P.; Stanek, B.; Pacher, R. B-type natriuretic peptide predicts sudden death in patients with chronic heart failure. Circulation 2002, 105, 2392-2397. [CrossRef] [PubMed]

38. Maisel, A.; Hollander, J.E.; Guss, D.; McCullough, P.; Nowak, R.; Green, G.; Saltzberg, M.; Ellison, S.R.; Bhalla, M.A.; Bhalla, V.; et al. Primary results of the Rapid Emergency Department Heart Failure Outpatient Trial (REDHOT). A multicenter study of B-type natriuretic peptide levels, emergency department decision making, and outcomes in patients presenting with shortness of breath. J. Am. Coll. Cardiol. 2004, 44, 1328-1333. [CrossRef]

39. Fonarow, G.C.; Peacock, W.F.; Phillips, C.O.; Givertz, M.M.; Lopatin, M.; ADHERE Scientific Advisory Committee and Investigators. Admission B-type natriuretic peptide levels and in-hospital mortality in acute decompensated heart failure. J. Am. Coll. Cardiol. 2007, 49, 1943-1950. [CrossRef]

40. Januzzi, J.L., Jr.; Sakhuja, R.; O’Donoghue, M.; Baggish, A.L.; Anwaruddin, S.; Chae, C.U.; Cameron, R.; Krauser, D.G.; Tung, R.; Camargo, C.A., Jr.; et al. Utility of amino-terminal pro-brain natriuretic peptide testing for prediction of 1-year mortality in patients with dyspnea treated in the emergency department. Arch. Intern. Med. 2006, 166, 315-320. [CrossRef]

41. Omland, T.; Aakvaag, A.; Bonarjee, V.V.; Caidahl, K.; Lie, R.T.; Nilsen, D.W.; Sundsfjord, J.A.; Dickstein, K. Plasma brain natriuretic peptide as an indicator of left ventricular systolic function and long-term survival after acute myocardial infarction. Comparison with plasma atrial natriuretic peptide and $\mathrm{N}$-terminal proatrial natriuretic peptide. Circulation 1996, 93, 1963-1969. [CrossRef] [PubMed]

42. Mega, J.L.; Morrow, D.A.; De Lemos, J.A.; Sabatine, M.S.; Murphy, S.A.; Rifai, N.; Gibson, C.M.; Antman, E.M.; Braunwald, E. B-type natriuretic peptide at presentation and prognosis in patients with ST-segment elevation myocardial infarction: An ENTIRE-TIMI-23 substudy. J. Am. Coll. Cardiol. 2004, 44, 335-339. [CrossRef] [PubMed]

43. Wang, T.J.; Larson, M.G.; Levy, D.; Leip, E.P.; Benjamin, E.J.; Wilson, P.W.; Sutherland, P.; Omland, T.; Vasan, R.S. Impact of age and sex on plasma natriuretic peptide levels in healthy adults. Am. J. Cardiol. 2002, 90, 254-258. [CrossRef]

44. Redfield, M.M.; Rodeheffer, R.J.; Jacobsen, S.J.; Mahoney, D.W.; Bailey, K.R.; Burnett, J.C. Plasma brain natriuretic peptide concentration: Impact of age and gender. J. Am. Coll. Cardiol. 2002, 40, 976-982. [CrossRef]

45. Wang, T.J.; Larson, M.G.; Levy, D.; Benjamin, E.J.; Leip, E.P.; Wilson, P.W.; Vasan, R.S. Impact of obesity on plasma natriuretic peptide levels. Circulation 2004, 109, 594-600. [CrossRef] [PubMed]

46. Mehra, M.R.; Uber, P.A.; Park, M.H.; Scott, R.L.; Ventura, H.O.; Harris, B.C.; Frohlich, E.D. Obesity and suppressed B-type natriuretic peptide levels in heart failure. J. Am. Coll. Cardiol. 2004, 43, 1590-1595. [CrossRef] [PubMed]

47. Bayes-Genis, A.; Lloyd-Jones, D.M.; van Kimmenade, R.R.; Lainchbury, J.G.; Richards, A.M.; Ordonez-Llanos, J.; Santalo, M.; Pinto, Y.M.; Januzzi, J.L., Jr. Effect of body mass index on diagnostic and prognostic usefulness of amino-terminal pro-brain natriuretic peptide in patients with acute dyspnea. Arch. Intern. Med. 2007, 167, 400-407. [CrossRef] [PubMed]

48. Horwich, T.B.; Hamilton, M.A.; Fonarow, G.C. B-type natriuretic peptide levels in obese patients with advanced heart failure. J. Am. Coll. Cardiol. 2006, 47, 85-90. [CrossRef]

49. Tsutamoto, T.; Wada, A.; Sakai, H.; Ishikawa, C.; Tanaka, T.; Hayashi, M.; Fujii, M.; Yamamoto, T.; Dohke, T.; Ohnishi, M.; et al. Relationship between renal function and plasma brain natriuretic peptide in patients with heart failure. J. Am. Coll. Cardiol. 2006, 47, 582-586. [CrossRef] 
50. Forfia, P.R.; Watkins, S.P.; Rame, J.E.; Stewart, K.J.; Shapiro, E.P. Relationship between B-type natriuretic peptides and pulmonary capillary wedge pressure in the intensive care unit. J. Am. Coll. Cardiol. 2005, 45, 1667-1671. [CrossRef]

51. McCullough, P.A.; Duc, P.; Omland, T.; McCord, J.; Nowak, R.M.; Hollander, J.E.; Herrmann, H.C.; Steg, P.G.; Westheim, A.; Knudsen, C.W.; et al. B-type natriuretic peptide and renal function in the diagnosis of heart failure: An analysis from the Breathing Not Properly Multinational Study. Am. J. Kidney Dis. 2003, 41, 571-579. [CrossRef]

52. Anwaruddin, S.; Lloyd-Jones, D.M.; Baggish, A.; Chen, A.; Krauser, D.; Tung, R.; Chae, C.; Januzzi, J.L., Jr. Renal function, congestive heart failure, and amino-terminal pro-brain natriuretic peptide measurement: Results from the ProBNP Investigation of Dyspnea in the Emergency Department (PRIDE) Study. J. Am. Coll. Cardiol. 2006, 47, 91-97. [CrossRef] [PubMed]

53. Gupta, D.K.; de Lemos, J.A.; Ayers, C.R.; Berry, J.D.; Wang, T.J. Racial Differences in Natriuretic Peptide Levels: The Dallas Heart Study. JACC Heart Fail. 2015, 3, 513-519. [CrossRef] [PubMed]

54. Gupta, D.K.; Daniels, L.B.; Cheng, S.; deFilippi, C.R.; Criqui, M.H.; Maisel, A.S.; Lima, J.A.; Bahrami, H.; Greenland, P.; Cushman, M.; et al. Differences in Natriuretic Peptide Levels by Race/Ethnicity (From the Multi-Ethnic Study of Atherosclerosis). Am. J. Cardiol. 2017, 120, 1008-1015. [CrossRef] [PubMed]

55. Jourdain, P.; Jondeau, G.; Funck, F.; Gueffet, P.; Le Helloco, A.; Donal, E.; Aupetit, J.F.; Aumont, M.C.; Galinier, M.; Eicher, J.C.; et al. Plasma brain natriuretic peptide-guided therapy to improve outcome in heart failure: The STARS-BNP Multicenter Study. J. Am. Coll. Cardiol. 2007, 49, 1733-1739. [CrossRef]

56. Lainchbury, J.G.; Troughton, R.W.; Strangman, K.M.; Frampton, C.M.; Pilbrow, A.; Yandle, T.G.; Hamid, A.K.; Nicholls, M.G.; Richards, A.M. N-terminal pro-B-type natriuretic peptide-guided treatment for chronic heart failure: Results from the BATTLESCARRED (NT-proBNP-Assisted Treatment To Lessen Serial Cardiac Readmissions and Death) trial. J. Am. Coll. Cardiol. 2009, 55, 53-60. [CrossRef]

57. Brunner-La Rocca, H.P.; Eurlings, L.; Richards, A.M.; Januzzi, J.L.; Pfisterer, M.E.; Dahlstrom, U.; Pinto, Y.M.; Karlstrom, P.; Erntell, H.; Berger, R.; et al. Which heart failure patients profit from natriuretic peptide guided therapy? A meta-analysis from individual patient data of randomized trials. Eur. J. Heart Fail. 2015, 17, 1252-1261. [CrossRef]

58. Pfisterer, M.; Buser, P.; Rickli, H.; Gutmann, M.; Erne, P.; Rickenbacher, P.; Vuillomenet, A.; Jeker, U.; Dubach, P.; Beer, H.; et al. BNP-guided vs symptom-guided heart failure therapy: The Trial of Intensified vs Standard Medical Therapy in Elderly Patients With Congestive Heart Failure (TIME-CHF) randomized trial. JAMA 2009, 301, 383-392. [CrossRef]

59. Morgenthaler, N.G.; Struck, J.; Thomas, B.; Bergmann, A. Immunoluminometric assay for the midregion of pro-atrial natriuretic peptide in human plasma. Clin. Chem. 2004, 50, 234-236. [CrossRef]

60. Maisel, A.; Mueller, C.; Nowak, R.; Peacock, W.F.; Landsberg, J.W.; Ponikowski, P.; Mockel, M.; Hogan, C.; $\mathrm{Wu}$, A.H.; Richards, M.; et al. Mid-region pro-hormone markers for diagnosis and prognosis in acute dyspnea: Results from the BACH (Biomarkers in Acute Heart Failure) trial. J. Am. Coll. Cardiol. 2010, 55, 2062-2076. [CrossRef]

61. Gegenhuber, A.; Struck, J.; Poelz, W.; Pacher, R.; Morgenthaler, N.G.; Bergmann, A.; Haltmayer, M.; Mueller, T. Midregional pro-A-type natriuretic peptide measurements for diagnosis of acute destabilized heart failure in short-of-breath patients: Comparison with B-type natriuretic peptide (BNP) and amino-terminal proBNP. Clin. Chem. 2006, 52, 827-831. [CrossRef] [PubMed]

62. Chenevier-Gobeaux, C.; Guerin, S.; Andre, S.; Ray, P.; Cynober, L.; Gestin, S.; Pourriat, J.L.; Claessens, Y.E. Midregional pro-atrial natriuretic peptide for the diagnosis of cardiac-related dyspnea according to renal function in the emergency department: A comparison with B-type natriuretic peptide (BNP) and N-terminal proBNP. Clin. Chem. 2010, 56, 1708-1717. [CrossRef] [PubMed]

63. Seronde, M.F.; Gayat, E.; Logeart, D.; Lassus, J.; Laribi, S.; Boukef, R.; Sibellas, F.; Launay, J.M.; Manivet, P.; Sadoune, M.; et al. Comparison of the diagnostic and prognostic values of B-type and atrial-type natriuretic peptides in acute heart failure. Int. J. Cardiol. 2013, 168, 3404-3411. [CrossRef] [PubMed]

64. Masson, S.; Latini, R.; Carbonieri, E.; Moretti, L.; Rossi, M.G.; Ciricugno, S.; Milani, V.; Marchioli, R.; Struck, J.; Bergmann, A.; et al. The predictive value of stable precursor fragments of vasoactive peptides in patients with chronic heart failure: Data from the GISSI-heart failure (GISSI-HF) trial. Eur. J. Heart Fail. 2010, 12, 338-347. [CrossRef] [PubMed] 
65. Smith, J.G.; Newton-Cheh, C.; Almgren, P.; Struck, J.; Morgenthaler, N.G.; Bergmann, A.; Platonov, P.G.; Hedblad, B.; Engstrom, G.; Wang, T.J.; et al. Assessment of conventional cardiovascular risk factors and multiple biomarkers for the prediction of incident heart failure and atrial fibrillation. J. Am. Coll. Cardiol. 2010, 56, 1712-1719. [CrossRef]

66. Daniels, L.B.; Clopton, P.; Potocki, M.; Mueller, C.; McCord, J.; Richards, M.; Hartmann, O.; Anand, I.S.; $\mathrm{Wu}$, A.H.; Nowak, R.; et al. Influence of age, race, sex, and body mass index on interpretation of midregional pro atrial natriuretic peptide for the diagnosis of acute heart failure: Results from the BACH multinational study. Eur. J. Heart Fail. 2012, 14, 22-31. [CrossRef] [PubMed]

67. Burke, M.A.; Cotts, W.G. Interpretation of B-type natriuretic peptide in cardiac disease and other comorbid conditions. Heart Fail. Rev. 2007, 12, 23-36. [CrossRef]

68. Fan, J.; Cao, H.; Su, L.; Ling, Z.; Liu, Z.; Lan, X.; Xu, Y.; Chen, W.; Yin, Y. NT-proBNP, but not ANP and $\mathrm{C}$-reactive protein, is predictive of paroxysmal atrial fibrillation in patients undergoing pulmonary vein isolation. J. Interv. Card. Electrophysiol. 2012, 33, 93-100. [CrossRef]

69. Martinez-Rumayor, A.; Richards, A.M.; Burnett, J.C.; Januzzi, J.L., Jr. Biology of the natriuretic peptides. Am. J. Cardiol. 2008, 101, 3-8. [CrossRef]

70. Arima, M.; Kanoh, T.; Kawano, Y.; Oigawa, T.; Yamagami, S.; Matsuda, S. Plasma levels of brain natriuretic peptide increase in patients with idiopathic bilateral atrial dilatation. Cardiology 2002, 97, 12-17. [CrossRef]

71. Inoue, S.; Murakami, Y.; Sano, K.; Katoh, H.; Shimada, T. Atrium as a source of brain natriuretic polypeptide in patients with atrial fibrillation. J. Card. Fail. 2000, 6, 92-96. [CrossRef]

72. Bai, M.; Yang, J.; Li, Y. Serum N-terminal-pro-brain natriuretic peptide level and its clinical implications in patients with atrial fibrillation. Clin. Cardiol. 2009, 32, E1-E5. [CrossRef] [PubMed]

73. Jourdain, P.; Bellorini, M.; Funck, F.; Fulla, Y.; Guillard, N.; Loiret, J.; Thebault, B.; Sadeg, N.; Desnos, M. Short-term effects of sinus rhythm restoration in patients with lone atrial fibrillation: A hormonal study. Eur. J. Heart Fail. 2002, 4, 263-267. [CrossRef]

74. Wozakowska-Kaplon, B. Effect of sinus rhythm restoration on plasma brain natriuretic peptide in patients with atrial fibrillation. Am. J. Cardiol. 2004, 93, 1555-1558. [CrossRef] [PubMed]

75. Bakowski, D.; Wozakowska-Kaplon, B.; Opolski, G. The influence of left ventricle diastolic function on natriuretic peptides levels in patients with atrial fibrillation. Pacing Clin. Electrophysiol. 2009, 32, 745-752. [CrossRef] [PubMed]

76. Schnabel, R.B.; Larson, M.G.; Yamamoto, J.F.; Sullivan, L.M.; Pencina, M.J.; Meigs, J.B.; Tofler, G.H.; Selhub, J.; Jacques, P.F.; Wolf, P.A.; et al. Relations of biomarkers of distinct pathophysiological pathways and atrial fibrillation incidence in the community. Circulation 2010, 121, 200-207. [CrossRef]

77. Svennberg, E.; Lindahl, B.; Berglund, L.; Eggers, K.M.; Venge, P.; Zethelius, B.; Rosenqvist, M.; Lind, L.; Hijazi, Z. NT-proBNP is a powerful predictor for incident atrial fibrillation-Validation of a multimarker approach. Int. J. Cardiol. 2016, 223, 74-81. [CrossRef]

78. Sinner, M.F.; Stepas, K.A.; Moser, C.B.; Krijthe, B.P.; Aspelund, T.; Sotoodehnia, N.; Fontes, J.D.; Janssens, A.C.; Kronmal, R.A.; Magnani, J.W.; et al. B-type natriuretic peptide and C-reactive protein in the prediction of atrial fibrillation risk: The CHARGE-AF Consortium of community-based cohort studies. Europace 2014, 16, 1426-1433. [CrossRef]

79. Shelton, R.J.; Clark, A.L.; Goode, K.; Rigby, A.S.; Cleland, J.G. The diagnostic utility of N-terminal pro-B-type natriuretic peptide for the detection of major structural heart disease in patients with atrial fibrillation. Eur. Heart J. 2006, 27, 2353-2361. [CrossRef]

80. Morello, A.; Lloyd-Jones, D.M.; Chae, C.U.; van Kimmenade, R.R.; Chen, A.C.; Baggish, A.L.; O’Donoghue, M.; Lee-Lewandrowski, E.; Januzzi, J.L., Jr. Association of atrial fibrillation and amino-terminal pro-brain natriuretic peptide concentrations in dyspneic subjects with and without acute heart failure: Results from the ProBNP Investigation of Dyspnea in the Emergency Department (PRIDE) study. Am. Heart J. 2007, 153, 90-97. [CrossRef]

81. Richards, M.; Di Somma, S.; Mueller, C.; Nowak, R.; Peacock, W.F.; Ponikowski, P.; Mockel, M.; Hogan, C.; $\mathrm{Wu}$, A.H.; Clopton, P.; et al. Atrial fibrillation impairs the diagnostic performance of cardiac natriuretic peptides in dyspneic patients: Results from the BACH Study (Biomarkers in ACute Heart Failure). JACC Heart Fail. 2013, 1, 192-199. [CrossRef] [PubMed] 
82. Knudsen, C.W.; Omland, T.; Clopton, P.; Westheim, A.; Wu, A.H.; Duc, P.; McCord, J.; Nowak, R.M.; Hollander, J.E.; Storrow, A.B.; et al. Impact of atrial fibrillation on the diagnostic performance of B-type natriuretic peptide concentration in dyspneic patients: An analysis from the breathing not properly multinational study. J. Am. Coll. Cardiol. 2005, 46, 838-844. [CrossRef] [PubMed]

83. Rogers, R.K.; Stoddard, G.J.; Greene, T.; Michaels, A.D.; Fernandez, G.; Freeman, A.; Nord, J.; Stehlik, J. Usefulness of adjusting for clinical covariates to improve the ability of B-type natriuretic peptide to distinguish cardiac from noncardiac dyspnea. Am. J. Cardiol. 2009, 104, 689-694. [CrossRef] [PubMed]

84. van Doorn, S.; Geersing, G.J.; Kievit, R.F.; van Mourik, Y.; Bertens, L.C.; van Riet, E.E.S.; Boonman-de Winter, L.J.; Moons, K.G.M.; Hoes, A.W.; Rutten, F.H. Opportunistic screening for heart failure with natriuretic peptides in patients with atrial fibrillation: A meta-analysis of individual participant data of four screening studies. Heart 2018, 104, 1236-1237. [CrossRef] [PubMed]

85. Kristensen, S.L.; Jhund, P.S.; Mogensen, U.M.; Rorth, R.; Abraham, W.T.; Desai, A.; Dickstein, K.; Rouleau, J.L.; Zile, M.R.; Swedberg, K.; et al. Prognostic Value of N-Terminal Pro-B-Type Natriuretic Peptide Levels in Heart Failure Patients With and Without Atrial Fibrillation. Circ. Heart Fail. 2017, 10, e004409. [CrossRef]

86. Kallergis, E.M.; Manios, E.G.; Kanoupakis, E.M.; Mavrakis, H.E.; Goudis, C.A.; Maliaraki, N.E.; Saloustros, I.G.; Milathianaki, M.E.; Chlouverakis, G.I.; Vardas, P.E. Effect of sinus rhythm restoration after electrical cardioversion on apelin and brain natriuretic Peptide prohormone levels in patients with persistent atrial fibrillation. Am. J. Cardiol. 2010, 105, 90-94. [CrossRef] [PubMed]

87. Beck-da-Silva, L.; de Bold, A.; Fraser, M.; Williams, K.; Haddad, H. Brain natriuretic peptide predicts successful cardioversion in patients with atrial fibrillation and maintenance of sinus rhythm. Can. J. Cardiol. 2004, 20, 1245-1248.

88. Lellouche, N.; Berthier, R.; Mekontso-Dessap, A.; Braconnier, F.; Monin, J.L.; Duval, A.M.; Dubois-Rande, J.L.; Gueret, P.; Garot, J. Usefulness of plasma B-type natriuretic peptide in predicting recurrence of atrial fibrillation one year after external cardioversion. Am. J. Cardiol. 2005, 95, 1380-1382. [CrossRef]

89. Solheim, E.; Off, M.K.; Hoff, P.I.; De Bortoli, A.; Schuster, P.; Ohm, O.J.; Chen, J. N-terminal pro-B-type natriuretic peptide level at long-term follow-up after atrial fibrillation ablation: A marker of reverse atrial remodelling and successful ablation. J. Interv. Card. Electrophysiol. 2012, 34, 129-136. [CrossRef]

90. Zhang, Y.; Chen, A.; Song, L.; Li, M.; Chen, Y.; He, B. Association Between Baseline Natriuretic Peptides and Atrial Fibrillation Recurrence After Catheter Ablation. Int. Heart J. 2016, 57, 183-189. [CrossRef]

91. Jiang, H.; Wang, W.; Wang, C.; Xie, X.; Hou, Y. Association of pre-ablation level of potential blood markers with atrial fibrillation recurrence after catheter ablation: A meta-analysis. Europace 2017, 19, 392-400. [CrossRef] [PubMed]

92. Deng, H.; Shantsila, A.; Guo, P.; Zhan, X.; Fang, X.; Liao, H.; Liu, Y.; Wei, W.; Fu, L.; Wu, S.; et al. Multiple biomarkers and arrhythmia outcome following catheter ablation of atrial fibrillation: The Guangzhou Atrial Fibrillation Project. J. Arrhythm. 2018, 34, 617-625. [CrossRef] [PubMed]

93. Roldan, V.; Vilchez, J.A.; Manzano-Fernandez, S.; Jover, E.; Galvez, J.; Puche, C.M.; Valdes, M.; Vicente, V.; Lip, G.Y.; Marin, F. Usefulness of N-terminal pro-B-type natriuretic Peptide levels for stroke risk prediction in anticoagulated patients with atrial fibrillation. Stroke 2014, 45, 696-701. [CrossRef] [PubMed]

94. Hijazi, Z.; Oldgren, J.; Andersson, U.; Connolly, S.J.; Ezekowitz, M.D.; Hohnloser, S.H.; Reilly, P.A.; Vinereanu, D.; Siegbahn, A.; Yusuf, S.; et al. Cardiac biomarkers are associated with an increased risk of stroke and death in patients with atrial fibrillation: A Randomized Evaluation of Long-term Anticoagulation Therapy (RE-LY) substudy. Circulation 2012, 125, 1605-1616. [CrossRef] [PubMed]

95. Hijazi, Z.; Wallentin, L.; Siegbahn, A.; Andersson, U.; Christersson, C.; Ezekowitz, J.; Gersh, B.J.; Hanna, M.; Hohnloser, S.; Horowitz, J.; et al. N-terminal pro-B-type natriuretic peptide for risk assessment in patients with atrial fibrillation: Insights from the ARISTOTLE Trial (Apixaban for the Prevention of Stroke in Subjects With Atrial Fibrillation). J. Am. Coll. Cardiol. 2013, 61, 2274-2284. [CrossRef] [PubMed]

96. Oldgren, J.; Hijazi, Z.; Lindback, J.; Alexander, J.H.; Connolly, S.J.; Eikelboom, J.W.; Ezekowitz, M.D.; Granger, C.B.; Hylek, E.M.; Lopes, R.D.; et al. Performance and Validation of a Novel Biomarker-Based Stroke Risk Score for Atrial Fibrillation. Circulation 2016, 134, 1697-1707. [CrossRef] [PubMed]

97. Hijazi, Z.; Lindback, J.; Alexander, J.H.; Hanna, M.; Held, C.; Hylek, E.M.; Lopes, R.D.; Oldgren, J.; Siegbahn, A.; Stewart, R.A.; et al. The ABC (age, biomarkers, clinical history) stroke risk score: A biomarker-based risk score for predicting stroke in atrial fibrillation. Eur. Heart J. 2016, 37, 1582-1590. [CrossRef] [PubMed] 
98. Eckstein, J.; Potocki, M.; Murray, K.; Breidthardt, T.; Ziller, R.; Mosimann, T.; Klima, T.; Hoeller, R.; Moehring, B.; Sou, S.M.; et al. Direct comparison of mid-regional pro-atrial natriuretic peptide with $\mathrm{N}$-terminal pro B-type natriuretic peptide in the diagnosis of patients with atrial fibrillation and dyspnoea. Heart 2012, 98, 1518-1522. [CrossRef]

99. Darkner, S.; Goetze, J.P.; Chen, X.; Henningsen, K.; Pehrson, S.; Svendsen, J.H. Natriuretic Propeptides as Markers of Atrial Fibrillation Burden and Recurrence (from the AMIO-CAT Trial). Am. J. Cardiol. 2017, 120, 1309-1315. [CrossRef]

100. van den Berg, M.P.; van Gelder, I.C.; van Veldhuisen, D.J. Depletion of atrial natriuretic peptide during longstanding atrial fibrillation. Europace 2004, 6, 433-437. [CrossRef]

101. Davies, M.J.; Pomerance, A. Pathology of atrial fibrillation in man. Br. Heart J. 1972, 34, 520-525. [CrossRef] [PubMed]

102. Seino, Y.; Shimai, S.; Ibuki, C.; Itoh, K.; Takano, T.; Hayakawa, H. Disturbed secretion of atrial natriuretic peptide in patients with persistent atrial standstill: Endocrinologic silence. J. Am. Coll. Cardiol. 1991, 18, 459-463. [CrossRef]

103. Yoshihara, F.; Nishikimi, T.; Sasako, Y.; Hino, J.; Kobayashi, J.; Minatoya, K.; Bando, K.; Kosakai, Y.; Horio, T.; Suga, S.-I.; et al. Plasma atrial natriuretic peptide concentration inversely correlates with left atrial collagen volume fraction in patients with atrial fibrillation. J. Am. Coll. Cardiol. 2002, 39, 288-294. [CrossRef]

104. Yoshida, K.; Tada, H.; Ogata, K.; Sekiguchi, Y.; Inaba, T.; Ito, Y.; Sato, Y.; Sato, A.; Seo, Y.; Kandori, A.; et al. Electrogram organization predicts left atrial reverse remodeling after the restoration of sinus rhythm by catheter ablation in patients with persistent atrial fibrillation. Heart Rhythm. 2012, 9, 1769-1778. [CrossRef] [PubMed]

105. Nakanishi, K.; Fukuda, S.; Yamashita, H.; Kosaka, M.; Shirai, N.; Tanaka, A.; Yoshikawa, J.; Shimada, K. Pre-procedural serum atrial natriuretic peptide levels predict left atrial reverse remodeling after catheter ablation in patients with atrial fibrillation. JACC Clin. Electrophysiol. 2016, 2, 151-158. [CrossRef]

106. Ogawa, K.; Yoshida, K.; Uehara, Y.; Ebine, M.; Kimata, A.; Nishina, H.; Takeyasu, N.; Noguchi, Y.; Ieda, M.; Aonuma, K.; et al. Mechanistic implication of decreased plasma atrial natriuretic peptide level for transient rise in the atrial capture threshold early after ICD or CRT-D implantation. J. Interv. Card. Electrophysiol. 2018, 53, 131-140. [CrossRef] [PubMed] 